\title{
Research Progress and Prospects of Betulinic Acid and Its Derivatives
}

\author{
Dhiraj Santosh Shinde ${ }^{1}$, Nilesh Bhosale ${ }^{2}$ \\ ${ }^{1}$ Department of Pharmaceutics. Pdea's Seth Govind Raghunath Sable College Of Pharmacy Saswad Pune Maharashtra, India (Pin- 411 04) \\ dhirajshinde765@gmail.com
}

Professor, Department of Pharmaceutics. Pdea's Seth Govind Raghunath Sable College Of Pharmacy Saswad Pune Maharashtra, India (Pin- 41104$)$

\begin{abstract}
Betulinic acid is the pentacyclic triterpenoids which occurred naturally then exhibits the potent anticancer activity. This review aims to compiling the published analytical method for the determination of the Betulinic acid. By using the techniques like UV visible spectrophotometry, High Performance Liquid Chromatography(HPLC),High Performance Thin Layer Chromatography (HPTLC) Tandem Mass Spectrometry, LC/MS/MS, Ultra Performance Liquid Chromatography (UPLC),Thin Layer Chromatography (TLC). Further method validation is carried out to ensure the method developed was accurate, specific, reproducible, precise over the specified range in which an analyte is analysed.
\end{abstract}

Keywords: Betulinic Acid, UV, HPLC, HPTLC, LC/MS/MS, GC, TLC

\section{Introduction}

Betulinic acid is pentacyclic triterpenoids discovered in 1995 in the stem bark Melaleuca cajuput showing the cytotoxicity towards a number of cancer cell line. Betulinic acid found in bark of many plants and it is an oxidation product of low molecular compound called Betulin a substance found in the outer bark of White Brich bark treeBetula alba. It acts as anticancer agent. It also used as antiproliferative, antinflammatory, anti-HIV, antimicrobial, antiretroviral, ${ }^{2}$ but it naturally exhibits the potent anticancer activity. ${ }^{1,3}$ Betulinic acid pure compound appears as White crystalline solid that melts at $295^{\circ} \mathrm{C}-297^{\circ} \mathrm{C}$. Betulinic acid was highly soluble in pyridine and acetic acid. The solubility of organic alcohol such as Methanol, Ethanol, Chloroform, Ether is reduced. Petroleum ether, Dimethyl formamide, Dimethyl sulfoxide, Benzene has low solubility. ${ }^{3}$

\subsection{Chemistry}

It is pentacyclic lupine type triterpene. It is $3 \beta$-hydroxy-lup20(29)-en-28-oic acid. IUPAC Name is1R, 3as, 5ar, 5br, 7ar, 9s, 11ar, 11br, 11br, 13ar, 13br) -9hydroxy -5a, 5b, 8, 8, 11a-pentamethyl-1prop-1-en-2-yl-1, 2, 3, 4, 5, 6, 7, 7a, 9, 10,11,11b, 12, 13, 13a, 13b-hexadecahydrocyclopenta[a] chr. Its chemical formula $\mathrm{C}_{30} \mathrm{H}_{48} \mathrm{O}_{3}$. Molecular weight is $456.7 \mathrm{~g} / \mathrm{mol}$. It is C-28 carboxylic acid derivative of triterpene betulin. ${ }^{4}$ Structure of Betulinic acid given in fig no 1 .

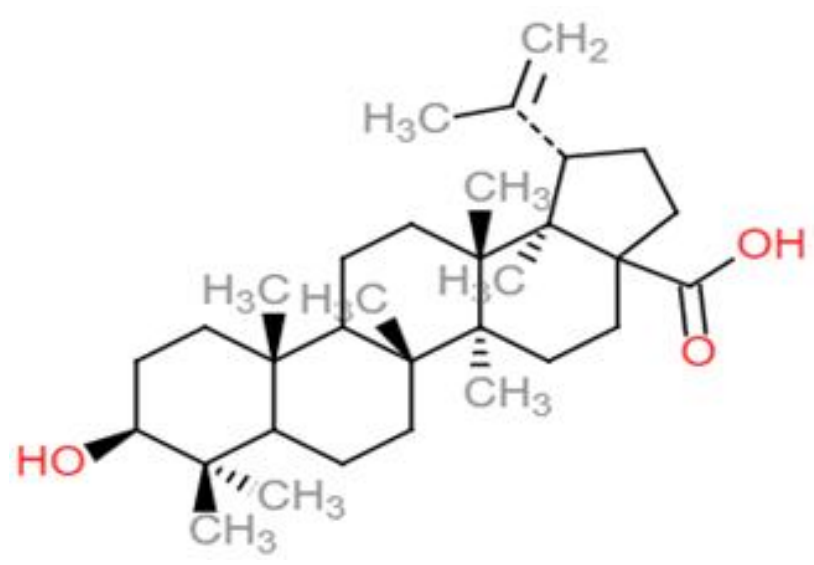

Figure 1: Structure of Betulinic Acid

\subsection{Mechanism of Action of Betulinic Acid}

Betulinic acid having potent anticancer activity. Its ability to induce apoptotic cell death in cancer cell by triggering the mitochondrial pathway of apoptosis. Apoptosis is an intrinsic program of cell death that is present in every cell and regulated by defined signalling pathway.

The main mechanism of anticancer action of Betulinic acid is known as the induction of apoptosis in cells, Betulinic acid induced the death cell which occurs due to cancer cell. That death of the of the normal cell is controlled by the Betulinic acid. The pathway for induction of the Betulinic acid is mitochondrial Pathway. The tumor suppression protein involved in apoptosis is the P53 (cellular tumour protein antigen).But the apotosis process is independent on the P53. The apoptosis in Mitochondrial membrane permeation in which the release of the cytochrome $-\mathrm{C}$ from the mitochondria and cytochrome-C dependent formation of a capase-3 activation complex. caspase -3 activation complex induces the death receptor and activates the pathway by which kill the cell in mitochondrial membrane permeation. Capacase also act in DNA fragmentation of cancer cell. ${ }^{3,4,5,6,7}$ 


\subsection{Pharmacology}

A) Pharmacokinetics: The pharmacokinetics and tissue distribution of Betulinic acid was studied in CD 1(cluster of differentiation 1) mice after i.p 250 and $500 \mathrm{mg} / \mathrm{kg}$ dose the serum concentration reached peak at 0.15 and $0.23 \mathrm{hr}$. The elimination half lives was $11.5 \mathrm{hr}$ and $11.8 \mathrm{hr}$. Total clearance of 13.6 and $13.5 \mathrm{~L} / \mathrm{kg} / \mathrm{h}^{3}$

B) Side effect: Betulinic acid is anticancer drug but it having less side effect such as diarrhoea, anorexia.

\section{Sample Preparation Strategies}

Sample preparation is integral part of analytical methodology and it was reported that approximately $30 \%$ error is contributed from sample analysis was due to sample preparation. The various diluents like Acetonitrile, Methanol, Water, Acetone, Ethanol. In major cases Acetonitrile and Methanol used as diluent. The sample preparation technique for the extraction of Betulinic acid by using Ethyl acetate, Hexane, Toluene, Formic acid.

\section{Analytical Method}

This all methods are used for determination of Betulinic acid. This all analytical method is reported during the literature survey. All reported analytical methods are at specific condition. The literature survey gives the number of methods for determination of betulinic acid.

\subsection{Spectrophotometry}

In the literature survey were found that UV spectrophotometric method have been reported for determination of Betulinic acid. In that the simultaneous method, derivative method, Q- absorption method, Area Under Curve etc. all are the method of UV spectroscopy for the determination of Betulinic acid but the simultaneous method was majorly used for the determination of Betulinic acid. $^{8,9}$

Table 1: Summary of UV spectrometric method of Betulinic acid

\begin{tabular}{|c|c|c|c|c|c|}
\hline S. No & Name of drug & Method & Wavelength & Solvent & Ref no \\
\hline 1 & Betulinic Acid & Simultaneous method & $210 \mathrm{~nm}$ & Ethanol & 1 \\
\hline 2 & Betulinic Acid & - & $210 \mathrm{~nm}$ & Ethanol & 10 \\
\hline
\end{tabular}

Table no 1- showed the summery of reported UV spectrometric methods indicating sample matrix used, $\lambda^{\max }$, solvent used in it.

\subsection{Chromatographic method}

The High Performance Liquid Chromatography for determination of Betulinic acid. Table no 2. Shows the summarized reported chromatographic method indicating sample, method, mobile phase composition, wavelength, Detector, LOQ, LOD.

According to the literature survey of the Betulinic acid by HPLC method, there are different method for determination of Betulinic acid such as Reverse Phase High Performance Liquid Chromatography, Isocratic High Performance Liquid Chromatography, Gradient High Performance Liquid Chromatography, Normal phase High Performance Chromatography etc. but the Reverse Phase High performance liquid Chromatography was majorly used.

Table 2: Summarized method for determination of the Betulinic acid by using HPLC

\begin{tabular}{|c|c|c|c|c|c|c|c|c|c|c|}
\hline Sr no & Drug & Combination & Mobile phase & Column & Detector & $\begin{array}{c}\begin{array}{c}\text { Flow rate } \\
\mathrm{ml} / \mathrm{min}\end{array} \\
\end{array}$ & $\begin{array}{l}\lambda \max \\
(\mathrm{nm}) \\
\end{array}$ & $\begin{array}{c}\mathrm{LOD} \\
\mu \mathrm{g} / \mathrm{ml}\end{array}$ & \begin{tabular}{|l|} 
LOQ \\
$\mu \mathrm{g} / \mathrm{ml}$
\end{tabular} & $\begin{array}{c}\text { Ref } \\
\text { no }\end{array}$ \\
\hline 1 & $\begin{array}{c}\text { Betulinic } \\
\text { acid }\end{array}$ & & $\begin{array}{l}\text { Methanol: acetonitrile: } \\
\text { water }(90: 5: 5 \mathrm{v} / \mathrm{v} / \mathrm{v})\end{array}$ & RP C18 column & UV & 1.3 & 270 & 0.144 & 0.436 & 12 \\
\hline 2 & $\begin{array}{c}\text { Betulinic } \\
\text { acid }\end{array}$ & Urosolic acid & $\begin{array}{l}\text { Acetonitrile: methanol } \\
(80: 20)\end{array}$ & C 18 column & $\mathrm{UV}, \mathrm{MS}$ & 0.5 & 210 & - & - & 11 \\
\hline 3 & $\begin{array}{l}\text { Betulinic } \\
\text { acid }\end{array}$ & Betulin & $\begin{array}{l}\text { Acetonitrile: } \\
\text { Water } \\
(86: 14 \mathrm{v} / \mathrm{v})\end{array}$ & $\begin{array}{c}\text { Diamonsil C18 Reversed } \\
\text { phase column }\end{array}$ & UV & 1 & 210 & 0.31 & - & 1 \\
\hline 4 & $\begin{array}{l}\text { Betulinic } \\
\text { acid }\end{array}$ & & $\begin{array}{c}\text { Acetonitrile: Methanol: } \\
\text { Acetic acid acidified } \\
\text { acid } \\
\text { water by pH } 2.8 \\
(70: 20: 10 \mathrm{v} / \mathrm{v} / \mathrm{v}) \\
\end{array}$ & $\begin{array}{l}\text { Reversed phase C18 column } \\
\text { (Hibar Rt } 250 \times 4 \mathrm{~mm} \text { i.d, } \\
\text { Lichrosrob RP } 18,10 \mu \mathrm{m})\end{array}$ & UV & 1 & 210 & 0.0005 & 0.0050 & 13 \\
\hline 5 & $\begin{array}{c}\text { Betulinic } \\
\text { acid }\end{array}$ & & $\begin{array}{c}\text { Acetonitrile: Methanol } \\
(80: 20)\end{array}$ & $\mathrm{C} 18(4.5 \times 250 \mathrm{~mm}, 5 \mu \mathrm{m})$ & UV & 0.5 & 210 & - & - & 14 \\
\hline 6 & $\begin{array}{c}\text { Betulinic } \\
\text { acid }\end{array}$ & & $\begin{array}{c}\text { Acetonitrile: Water } \\
(15: 15 \mathrm{v} / \mathrm{v})\end{array}$ & $\begin{array}{l}\text { Reverse phase Hypersil C18 } \\
\text { column }, 250 \mathrm{~mm}\end{array}$ & PDA & 1 & 210 & $8.24 \mathrm{ppm}$ & $\begin{array}{l}24.73 \\
\mathrm{ppm}\end{array}$ & 15 \\
\hline 7 & $\begin{array}{l}\text { Betulinic } \\
\text { acid }\end{array}$ & Urosolic acid & $\begin{array}{l}\text { Acetonitrile: Water } \\
(90: 10 \mathrm{v} / \mathrm{v})\end{array}$ & Reversed phase $\mathrm{C} 18$ column & UV & 1 & 210 & 0.268 & 0.878 & 16 \\
\hline 8 & $\begin{array}{c}\text { Betulinic } \\
\text { acid }\end{array}$ & & $\begin{array}{l}\text { Acetonitrile: Water } \\
(92: 08 \mathrm{v} / \mathrm{v})\end{array}$ & $\begin{array}{c}\text { C18 column }(250 \mathrm{~mm} \times 4.6 \mathrm{~mm} \text {, } \\
5 \mathrm{~mm}\end{array}$ & DAD & 1 & 205 & 0.1 & 0.3 & 17 \\
\hline
\end{tabular}




\subsection{HPTLC}

indicating sample, wavelength, mobile phase composition,

HPTLC method for determination of Betulinic acid. Table linearity, retention factor. no 3- shows the summarized reported HPTLC method

Table 3: Summary HPTLC Method of Betulinic acid

\begin{tabular}{|c|c|c|c|c|c|c|c|}
\hline S. no & Drug name & Combination & Mobile phase & Linearity & Amax & RF & Ref .no \\
\hline 1 & Betulinic acid & - & $\begin{array}{c}\text { Hexane: ethyl acetate } \\
(6: 4 \mathrm{v} / \mathrm{v})\end{array}$ & $0.2-500 \mu \mathrm{g}$ & $366 \mathrm{~nm}$ & - & 18 \\
\hline 2 & Betulinic acid & - & $\begin{array}{c}\text { Toluene: ethylacetate: methanol } \\
(16: 2: 2 \mathrm{v} / \mathrm{v})\end{array}$ & $0.99 \mu \mathrm{g}$ & $540 \mathrm{~nm}$ & 0.67 & 10 \\
\hline 3 & Betulinic acid & - & $\begin{array}{c}\text { Hexane: Ethyl acetate: Formicacid } \\
(3: 2: 0.02 \mathrm{v} / \mathrm{v} / \mathrm{v})\end{array}$ & $0.005-100 \mu \mathrm{g} / \mathrm{ml}$ & $366 \mathrm{~nm}$ & - & 13 \\
\hline 4 & Betulinic acid & $\begin{array}{c}\text { UA, BA, } \\
\text { LUP, STGM. }\end{array}$ & $\begin{array}{c}\text { PET ET: ethyl acetate: toluene } \\
(7: 2: 1 \mathrm{v} / \mathrm{v} / \mathrm{v})\end{array}$ & $100-600 \mathrm{ng} / \mathrm{ml}$ & $540 \mathrm{~nm}$ & $\begin{array}{c}\text { UA-O.21 } \\
\text { BA-0.2 } \\
\text { LUP-0.50 } \\
\text { STGM-0.33 }\end{array}$ & 19 \\
\hline 5 & Betulinic acid & - & $\begin{array}{c}\text { Toluene: Methanol: Formic acid } \\
(8: 1: 1 \mathrm{v} / \mathrm{v} / \mathrm{v})\end{array}$ & $0.2-1.2 \mu \mathrm{g}$ & $540 \mathrm{~nm}$ & 0.47 & 20 \\
\hline
\end{tabular}

\subsection{UPLC (Ultra Performance Liquid Chromatography)}

Betulinic acid was determined in the extract of Disporosis pernyi diels by Ultra Performance Liquid Chromatography. UPLC analysis was done by using Shim Pack XR-DDS column with gradient elution. Mobile phase was Acetonitrile: water: formic acid. Flow rate was $0.2 \mathrm{ml} / \mathrm{min}$. Detection of Betulinic acid at $210 \mathrm{~nm}$. Linearity was found to be $48.34-338.10 \mu \mathrm{g} / \mathrm{ml}$. Regression coefficient was found to be 0.999 . LOD was found to be $0.137 \mu \mathrm{g} / \mathrm{ml}$.LOQ was found to be $0.456 \mu \mathrm{g} / \mathrm{ml}$. $^{(21)}$

\subsection{LC-MS (Liquid Chromatography - Tandem Mass Spectrometry) method}

Development and validation of Betulinic acid in rat plasma by using Liquid chromatography -Tandem mass spectrometry method. An agela MG- C18 analytical column $(50 \times 2.1 \mathrm{~mm} 5 \mu \mathrm{m})$. mobile phase was methanol: water: formic acid $(80: 20: 0.1 \mathrm{v} / \mathrm{v} / \mathrm{v})$. flow rate is $0.6 \mathrm{ml} / \mathrm{min}$. Mass detection was conducted by electrospray ionization. Milli Q ultrapure water purification system used for deionized water used in LC-MS-MS. Linearity was $3 \mathrm{ng} / \mathrm{ml}$. $\mathrm{R}^{2}$ was 0.9961 0.9976 . Interday precision $<7.8$, Intraday precision $>5.7{ }^{(22)}$

Simultaneous quantification of Betulinic acid madhuca longifolia methanolic extract of bark by using LC-MS. Stationary phase Gemini C18 column $(50 \mathrm{~mm} \times 2 \mathrm{~mm}, 3 \mu \mathrm{m})$. mobile phase acetonitrile: methanol $(50: 50 \mathrm{v} / \mathrm{v})$. run time 5min. Flow rate was $0.4 \mathrm{ml} / \mathrm{min}$. Retention time for Betulinic acid was 1.25 . $^{(23)}$

Quantitative analysis of Betulinic acid in rat plasma by using LC- MS, for analysis isocratic reversed phase system coupled to negative ion electrospray mass spectrometer, Agilent G19 G6A LCMSD quadrupole mass spectrometer equipped with a series 1100 HPLC binary pump. C18 column [ $5 \mu \mathrm{m}: 250 \times 2.1 \mathrm{~mm}$ ]. $90 \%$ acetonitrile: water used as mobile phase. Flow rate $0.2 \mathrm{ml} / \mathrm{min}$. LOD was found to be $0.5 \mathrm{pg}$. LOQ was found to be $2 \mathrm{pg}$. Intraday precision was found to be 9\%, Inter day precision $5.9 \%$ regression coefficient $\left(r^{2}\right)$ was found to be $0.999 .{ }^{(24)}$
Determination of Betulinic acid by using LC-MS method, using positive electron spray ionization, isocratic, column C18 RP $(150 \quad \mathrm{~mm} \times 4.6 \mathrm{~mm} \quad 5 \mu \mathrm{m}) . \quad 80 \%$ acetonitrile: ammonium acetate. flow rate $1 \mathrm{ml} / \mathrm{min}$. LOD was 0.087 $\mu \mathrm{g} / \mathrm{ml}$. LOQ was $0.266 \mu \mathrm{g} / \mathrm{ml}$. Repeatability was $1.6 \%$. intermediate precision was $2.07 \%$. ${ }^{25)}$

\subsection{GC/ MS (Gas chromatography - mass spectroscopy)} method:

Analysis of the presence of Betulinic acid in the leaves of Eugenia florida by Gas chromatography-mass spectroscopy, GC/FID. GC performed by $6890 \mathrm{~N}$, HP 5 column $(50 \times 0.25 \mathrm{~mm}, 0.25 \mu \mathrm{m}$, liquid phase). Oven temperature was maintained $70^{\circ} \mathrm{c}-300^{\circ} \mathrm{c}$ at $5^{\circ} \mathrm{clmin}$. carrier gas was helium 11 $3 \mathrm{~L} / \mathrm{min}$. split mode 20:1. $\mathrm{R}^{2}$ was found to be 0.9994 . Linearity for GC/FID was found to be $0.1-0.5 \mu \mathrm{g} / \mathrm{ml}$. ${ }^{(26)}$

Abbreviation-UV-UV-Visible spectroscopy, HPLC- High Performance Liquid Chromatography, HPTLC- High Performance Thin Layer Chromatography, UPLC- Ultra Performance Liquid Chromatography, LC- Liquid Chromatography, GC- Gas Chromatography, MS- Mass Spectroscopy, LOD-Limit of Detection, LOQ- Limit of Quantification, UA- Urosolic acid, LUP- Lupeol, PET-ETPetroleum Ether, STGM - Stigmasterol,

\section{Discussion}

The different analytical methods are used for the determination of the Betulinic acid. The presented review helps to decide which mobile phase, stationary phase, instrument was gives the better analysis of Betulinic acid. Review gives the different technique so analyst can select the proper technique for the determination of Betulinic acid. The effective combination parameter should minimize the cost of the analysis, reduce the time by using the selective analytical method.

\section{Conclusion}

The Review article presented the analytical method for determination of Betulinic acid. The literature survey of analytical data exhibits that HPLC methods are primarily for the analysis of Betulinic acid. Determination of Betulinic 
acid is also done by the HPTLC, GC-MS, UV, LC-MS method, concluded the method developed was accurate, specific, precise, reproducible. The presented information is useful for the future prospective study for researcher in analysis of Betulinic acid.

\section{Acknowledgements}

The author would like to acknowledge Principle Dr. R.S. Chavan. Pdea's Seth Govind Raghunath Sable College Of Pharmacy Saswad, Pune for providing laboratory facilities and encouragement.

\section{Conflict of Interest}

The author shows that there is no conflict of interest.

\section{References}

[1] Guoling Zhao, Weidong Yan, Dan Cao. Simultaneous determination of Betulin and Betulinic acid in White birch Bark using RP-HPLC. Journal of Pharmaceutical and Biomedical Analysis, 2007; (43): 959-962.

[2] Perumal Yogeeswari, Dharmarajan Sriram Betulinic Acid and Its Derivatives: A Review on their Biological Properties Current Medicinal Chemistry, 2005, 12, 657-666

[3] Gomathi Periasamy, GirmaTeketelew, Mebrahtom Gebrelibanos, Biruk Sintayehu, Michael Gebrehiwot, Aman Karim and Gereziher Geremedhin. Betulinic acid and its derivatives as anti-cancer agent: A review. 2014, 6(3), 47-48.

[4] Simone Fulda and Klaus-Michael Debatin. Sensitization for Anticancer Drug-Induced Apoptosis by Betulinic Acid. Neoplasia, 2005, 7(2), 162 - 170.

[5] Thangaiyan Rabi, Sanjeev Shukla, Sanjay Gupta. Betulinic Acid Suppresses Constitutive and TNFaInduced NF-kB Activation and Induces Apoptosis in Human Prostate Carcinoma PC-3 Cells. MOLECULAR CARCINOGENESIS 47:964-973 (2008)

[6] Sudhakar Chintharlapalli, Sabitha Papineni, Shashi K. Ramaiah, et a. Betulinic Acid Inhibits Prostate Cancer Growth through Inhibition of Specificity Protein Transcription Factors. Cancer Research, 2007;67:2816-2823.

[7] Inqo Muckenschanabel, Gunther Bernhardt, Thilo Spruss, Armin Buschauer. Pharmacokinetics and tissue distribution of bovine testicular hyaluronidase and vinblastine in mice an attempt to optimize the mode of adjuvant hyaluronidase administration in cancer chemotherapy. Cancer letter, 1998;131:71-84.

[8] Dipali M Atole, Hrishikesh H Rajput. Ultraviolet Spectroscopy and Its Pharmaceutical Applications- A Brief Review. Asian Journal Pharmaceutical Clinical Research, 2018;11(2): 59-66

[9] Amira H.Kamal, Samah F. El-Malla And Sherin F. Hammad. A Review On UV Spectrophotometric Methods for Simultaneous Multicomponent Analysis. Ejpmr, 2016,3(2), 348-360

[10] BhaveRaginiKedar, Barve S.S. HPTLC method validation for detection and quantification of Betulinic acid in Ancistrocladus Heyneanus wall Ex. J Graham. IJPPS, 2014, 6 (8).

[11] S.V. Taralkar, S. Chattopadhyay. A HPLC method determination of urosolic acid and Betulinic acid from their methanolic extract of vitex negudolinn. $\mathrm{J}$ and Bioanal Technique, 2012, 3(2).

[12] Patel. R.K, Trivedi P.D, Development and validation for Quantification of Betulinic acid in vitex negundo and its polyherbal formulation. IJPSR 2016,7(2), 856- 861.

[13] Khalid Hussain, Muhmmad Tanveer Khan, Zhari Ismail, AmirinSdaikun. Rapid separation and determination of Betulinic acid from a complex matrix using combination of TLC and RP-HPLC. 2012, 25(2) $-413-422$.

[14] Adelele GE, Arindeoo, Fatoki Jo. Identification of Betulinic acid in ethanol extract of vitellaria paradoxaleaves using spectroscopy and HPLC. 2018, 7 (5) - 571- 576.

[15] Preet Amol Singh, N.B. Brindavanam, G.P. Kimothi, Rajesh Verma, Vidhi Aeri. A validated HPLC method for the determination of Betulin in the stem bark of Tectona Grandis Linn. IJPSR, 2016, 7(2) - 719-723. 